\title{
明るさの繼時比較に於ける陽性時間錯誤に就いて \\ ON THE POSITIVE TIME-ERROR IN THE SUCCESSIVE COMPARISON OF BRIGHTNESS
}

\begin{tabular}{rrr}
\hline 小 & 野 & 茂* \\
By & ONo, & SHIGERU \\
\hline
\end{tabular}

\section{I 問 題}

Köhler の繼時比較に閵する賽騟的呼究以來，その錯 誤法時閒々隔の函數として變化する事分明らかになつた 即ち時間々隔が短い時には陽性時間錯誤があらわれ，時 間々隔が長くなるにつれて陰性時間錯誤の傾向老增す。

（更に時間々隔が長くなると，時間錯誤が消失する。本 論文では，此の樣に極めて長い時間々隔の時間錯誤には 諭及しない)時間々隔が長い場合の陰性時間錯誤につい ては，Lauenstein の同化誯（6）劣容認して差仕えない ですろう。しかしふがら同化倹が現在の形のまっで完全 ‘゙あると云うのではない。繼續實驗に依る時間錯誤曲線 の戀容は闹化證によつては證明が困難ではあるまいか (9)。無刺㦸の浪跡との同化と云ら事が果して妥當であ るか (11)。又地刺战兄の同化の程度は單純に地刺㦸の 强度々一義的に對雄ぜず，同化對比曲線を描くが此の點 については Lauenstein は觸れていないではないか(12) 等々の批制が既になされて居り，同化說に呤味の餘地が ある事を示している。文本論文の賔驗結果も同化說に對 して若干の補正追加を余儀なくせしめるであろう。

问化證によつて陰性時間錯俁の理論は飛躍的な淮步を 逐げたが，時間々隔の短い時の陽性時間錯誤については 未ナ゙定說がなく，諸說紛紏している現狀である。本論文 の筫驗は此の分野に何等かの光明を求めようとして行わ れたものである。先ず從來述べられてきた短い時間々隔 に於ける陽性時間錯誤に關する學镜及び事筫に就いて散 見した所を述べよう。

(1) Lauenstein $(6,7)$ に依孔ば. 音强度及び明るさ の繼時此較に於いて，短い時間々隔に於汁る陽性時間鐠

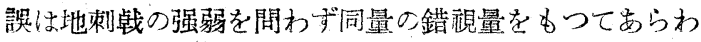
れる。久の故をるつて彼は此の現象は長い、時間及隔に扔 ける時間錯俁とは異つた日子によるものだあるとなし た。

(2) 之に對して和田氏 $(13,14)$ が次の洯に批制してい る。音强度の繼時比較において，地刺㦸の强度を適當に

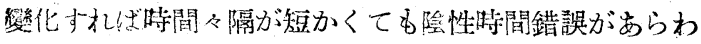
れる。そ机故長短兩㭙間々隔における時間錯琎は同一の 因于によるものとして考える方が妥當である。即り第 1
の比翰對象の㾗跡は最初對比的に變容し，その後澌次に 同化六と移るものである。

(3) Kreezer (5) は繼特比較における時間錯誤の問題 を生理學的水準から考察し，明るさについて富羷を行つ た結果次の樣にサヂェストしている。㓌性時間錯誤は大 腦皮質の因子 (cortical factor) によるものであり，陽性 時間錯誤は神經傳導路の制止殘勎 (inhibitory after-effect）によるるのであろち。

(4) 豆强度の繼時比較において，實驗を繼續して行万 と時間々隔の短い場合の陽性特間錯誤は陰性特間錯誤え と變容する $(9)$ 。

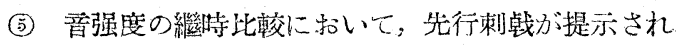

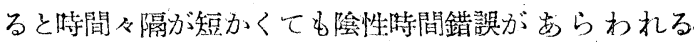
(8)。

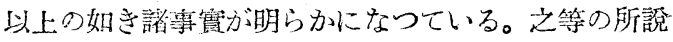
を念頭に扣きつ〉霣羷をす〉めてゆきたい。さて此處で 簡單に我々の意國する所を述べておこう。一般に陽性時 間錯誤が另らわれるのは第 1 に前述の栤に時間々隔が短 い場合，第 2 に地刺钱の强度が比較すべき刺钱より强い 場合でまる。我々は此の2つの事實を同一の機制に依る ものと見たい。此の樣な見地は一見和田氏の時間錯誤全 體を一元的に見ようとする說に包括される橙であるが，

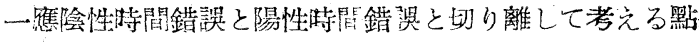
で我々の見地とは區別される。又同樣の點で，上述の Lauenstein の學說とも椌る。我々の見地はむしろ一 その神經生理學的假定はしばらくおき—除陽雨性時間 錯哭が夫ょ巽る因子によるものとなした主張に類似して いる。

以上の橙な觀點から明るさを比較對象として窟驗を行 らので多るが，主として地刺战がより明るい場合につい て考察し，之の中より時間々隔が短い場合の陽性時間錯 誤を子證明する要因を引佸し陽性時間錯誤理論を確立し たいと思う。

\section{1 裝置及び方法}

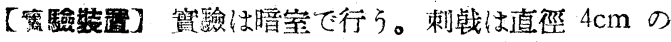
圆形のナりガラスに後から $4 \mathrm{~V}$ の豆球によつて照らした ものを用いた。Vp.の眼と刺战との距離は $18.5 \mathrm{~cm}$ で要

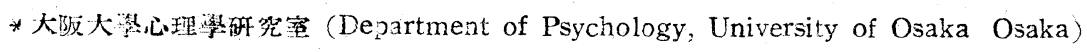




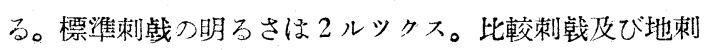
械, 副次刺钱の明るさは抵抗器によつて調節する。

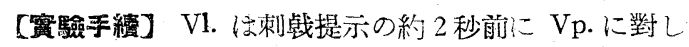

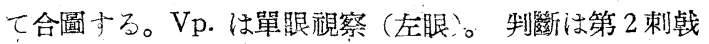
の方が第 1 刺钱よりも「明るい」暗い」等しい」或い は「疑わしい,の4種類で Vp. は制饌成立の際, V1に 對し口答で報告する。

(略字) 記述を簡單にする第, 次の如き略字を用いる

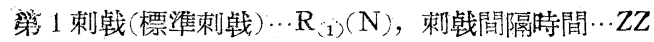

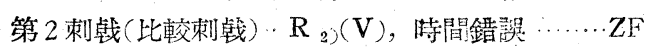

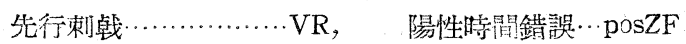
中間刺战……….....MR, 陰性洔間錯誤‥negZF 刺战提示時間……....DZ

【蚠騷方法】恒常法による。V の明るさは 5 種類。I を最明， $\mathrm{V}$ を最暗とすれば，III は $\mathrm{N}$ の明るさと等し い。IはIIIよりも $2.4 \Omega$ だけ抵抗が少い。II は $1.2 \Omega$ 少い。IV は III よりも $1.2 \Omega$ 多い。V は $2.4 \Omega$ 多い。

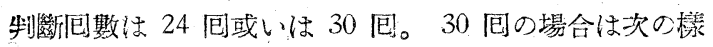
な組合せを不規則な順序を提示する。(III-I) (III-II) (III-IV) (III-V) 各 5 尼，(III-III) 10 问。24包の 場合は 30 四の場合から (III-III)を2四, 他を1司減 じたものでする。刺㦸の提示は $\mathrm{N}-\mathrm{V}$ の順序。結果の 整理は Lauens ein に從い，D\%= $\frac{\mathrm{D}-\mathrm{H}}{\mathrm{N}} \times 100$ を算 出して之によつて ZF の量劣指示した。(但し D は $\mathrm{R}_{(2)}$ ) がより暗い制新數，H はより明るい制邀数，N は總制 㫁數)

[被䮦,j]王里學專攻學生

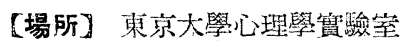

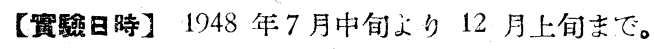

\section{III 予鹤實驗}

先ず我々の實噞においても， $\left.R_{1}\right)$ と $R_{(2)}$ の $Z Z$ が短 い時及び地刺㦸吕比較すべき刺戲よりも明るい場合に posZF があらわ的るか否かを追試する。

-Exp. I-

【目的】 $\mathrm{R}_{(1)}$ と $\mathrm{R}_{2}$ ) の間の $Z Z$ が短い時, posZF が あらわれるか否かを考察する。

【條】 $\mathrm{R}_{(1)}, \mathrm{R}_{(2)}$ の $\mathrm{DZ}$ は各 2 秒。 $\mathrm{R}_{1}$ )と $\mathrm{R}_{2}$ )の 間の $Z Z$ は 1, 3, 6, 9 秒。

[Vp.] Ot, M, St, Sy 94 名。

【結硔】表 I の如くである。我々の貫驗においても ZZ が短い時には posZF があらわれる。

-Exp. $\mathrm{I}$ -

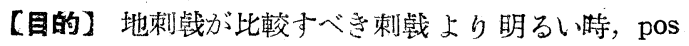
ZF があらわれるか否かを考察小る。

【修性】 $\left.\mathrm{R}_{1}\right)$ と $\mathrm{R}_{2}$ ）の $\mathrm{DZ}$ は各2 秒。地刺战は $\mathrm{R}_{(1)}$ の 4 秒前より $\mathrm{R}_{2}$ ）の 2 秒後まで提示寸る。地刺戙の明 るさは $\mathrm{N} よ り 3.6 \Omega$ だけ抵抗を減じだもので，照度は 3.8 ルックス。 $\mathrm{R}_{(1)}$ と $\mathrm{R}_{(2)}$ の聞の $\mathrm{ZZ}$ は $1,3,6,9,12$ 秒

[Vp] Ot, St, $\mathrm{Ay}, \mathrm{Az} の 4$ 名。

【結鼠] 表 II の如くである。我々の實驗においても 地刺戲が比較すべき刺㦸より明るい時には posZF があ らわれる。䏌此處で一言して招きたい事は $R_{(2)}$ に後續 する地刺㦸心ついてで市る。比較過程に關する多くの現

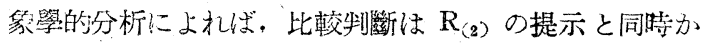
或いはその寸前に成立すると云われているが，我々の實

\section{I}

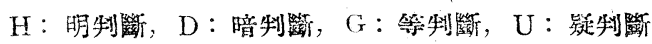

\begin{tabular}{|c|c|c|c|c|c|c|c|c|c|c|c|c|c|c|c|c|c|c|c|c|c|c|c|c|c|}
\hline $\mathrm{Vp}$ & \multicolumn{5}{|c|}{ Ot } & \multicolumn{5}{|c|}{$\mathrm{M}$} & \multicolumn{5}{|c|}{ St } & \multicolumn{5}{|c|}{ Sy } & \multicolumn{5}{|c|}{ 計 } \\
\hline $\begin{array}{l}\text { 刵断 } \\
\mathrm{ZZ}\end{array}$ & $\mathrm{H}$ & $D$ & $\mathrm{G}$ & $\mathrm{U}$ & $D \%$ & $\mathrm{H}$ & $\mathrm{D}$ & $\mathrm{G}$ & $\mathrm{U}$ & $\mathrm{D} \%$ & $\mathrm{H}$ & $\mathrm{D}$ & $\mathrm{G}$ & $\mathrm{U}$ & $\mathrm{D} \%$ & $\mathrm{H}$ & $\mathrm{D}$ & $\mathrm{G}$ & $\mathrm{U}$ & $0 \%$ & $\mathrm{H}$ & D & $\mathrm{G}$ & $\mathrm{U}$ & $D \%$ \\
\hline 1 & 6 & $19^{\circ}$ & 4 & 1 & 43 & 8 & 17 & 5 & 0 & +30 & 9 & 14 & 6 & 1 & +17 & 12 & 14 & 2 & 2 & +7 & 35 & 64 & 17 & & +24 \\
\hline 3 & 11 & 11 & 7 & 1 & 0 & 12 & 15 & 0 & 3 & +10 & 9 & 9 & 11 & 1 & 0 & 14 & 9 & 5 & 2 & -17 & 46 & 44 & 23 & 7 & -2 \\
\hline 6 & 13 & 13 & 4 & 0 & 0 & 14 & 12 & 4 & 0 & -7 & 11 & 8 & 10 & 1 & -10 & 16 & 9 & 4 & 1 & -23 & 54 & 42 & 22 & 2 & -10 \\
\hline 9 & 17 & 9 & 3 & 1 & -27 & 13 & 10 & 7 & 0 & -10 & 16 & 7 & 7 & 0 & -30 & 15 & 8 & 6 & 1 & $-23 \mid$ & 61 & 34 & 23 & & -23 \\
\hline
\end{tabular}

表

$\mathbb{I}$

\begin{tabular}{|c|c|c|c|c|c|c|c|c|c|c|c|c|c|c|c|c|c|c|c|c|c|c|c|c|c|}
\hline Vp. & \multicolumn{5}{|c|}{ Ot } & \multicolumn{5}{|c|}{ St } & \multicolumn{5}{|c|}{ Ay } & \multicolumn{5}{|c|}{$\mathrm{Az}$} & \multicolumn{5}{|c|}{ 計 } \\
\hline $\mathrm{ZZ}$ & $\mathrm{H}$ & D & G & U & $D \%$ & $\mathrm{H}$ & D & G & $\mathrm{U}$ & $D \%$ & $\mathrm{H}$ & $\mathrm{D}$ & $\mathrm{G}$ & $\mathrm{U}$ & $\mathrm{D} \%$ & $\mathrm{H}$ & D & G & U & $\%$ & $\mathrm{H}$ & $\mathrm{D}$ & $\mathrm{G}$ & $\mathrm{U}$ & $D \%$ \\
\hline 1 & 9 & 19 & 2 & 0 & +33 & 10 & 9 & 7 & 4 & -3 & 11 & 12 & 7 & 0 & +3 & 9 & 15 & 3 & 3 & +20 & 39 & 55 & 19 & 7 & +13 \\
\hline 3 & 7 & 22 & 1 & 0 & +50 & 8 & 14 & 8 & 0 & +20 & 11 & 13 & 6 & 0 & +7 & 7 & 15 & 6 & 2 & +27 & 33 & 64 & 21 & 2 & +26 \\
\hline 6 & 6 & 21 & 3 & 0 & +50 & 7 & 13 & 10 & 0 & +20 & 8 & 16 & 5 & 1 & +27 & 7 & 15 & 6 & 2 & +27 & 28 & 65 & 24 & 3 & +31 \\
\hline 9 & 5 & 25 & 0 & 0 & +67 & 7 & 15 & 7 & 1 & +27 & 8 & 18 & $T$ & 0 & +33 & 7 & 15 & 4 & 4 & +27 & 27 & 73 & 15 & 5 & +38 \\
\hline 12 & 5 & 19 & 6 & 0 & +47 & 7 & 11 & 12 & 0 & +13 & 7 & 16 & 7 & 0 & +30 & 8 & 13 & 2 & 7 & +17 & 27 & 59 & 27 & 7 & +27 \\
\hline
\end{tabular}


羷においても同樣の事が Vp.によつて報告された。從 つて $R_{2}$ ) に後續する地刺战は比較判斷の成立にとつて 本質的意義を孔たない橉に思われる。以下本論文に山い て $\mathrm{R}_{(2)}$ に後續する地刺钱を問題としないのは此の理由 に依る。又 $\mathrm{Vp}$ の內筧で重要な事は， $\mathrm{R}_{1}$ に先行する 地刺钱より， $\mathrm{R}_{1}$ )と $\mathrm{R}_{2}$ ）の間を埋める地刺钱の方が暗 く見えると云う事である。此の內觀の意䣡については後 に述べるつもりであるから此處では單に注意しておくに とら゙める。更に又「地刺㦸力゙地としての現象的特性を持 たない場合がしばしばある」と云う內觀報告をVp.か

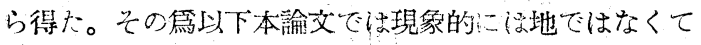
め，客觀的に地として刺㦸意提示した場合はすべて地刺 战と稱する事にする。之は本來の語義に反する事である が，記述の便宜上此の樣な用法を探つた。

\section{IV よリ明るい地制韩と陽性時間錯誤 [I 一中間剌䇅について—}

豫備實驗によつて $Z Z$ が短い場合及び地刺敦がより明 るい場合には posZF があらわれる事が再確認された。 以下後者に關して考察をす〉める。その第に地剌㦸を VR と MR とに分けてその各々が ZF に對して擔う機 能を見てゆきたい。（その場合，上り明るい地刺戱が間題 なのであるから，より明るいVR. MR を考察の主對象 とする事は論を俟たない）さて VR や MR が單獨に提 示されてを時は，勿論それ等は地としての特性を持たない それでは「地刺战をVR と MR とに分析して考えては 地刺戱を解明する事にはならないのではないか」と云う 疑間がおこるであろら。此の疑間に對して答えていこう Exp. II に扔いて「地刺钱力゙地としての性格を持ない場 合がある」と云う內觀報告を得た事は既述の如くである
が，此の場合にもZF は地刺战が地として把えうれた埸 合と同樣の擧措を示すのである。乞うすると，我々が問 題としている分野に限り, 地刺钱の地としての性格は考 慮の範園外にあるのではなからうか。此の樣な理由から 地刺战学 MR とVRに分け, 本節では先ず MRを取 り出し $M R の Z F$ に對する機能を明らかにし上うと思 5 .

さて MRに關しては，すでに Pratt (11) 及び Needham (10) が卑强度の繼時比較において MR の强度ふ： 比較すべき刺㦸より强い場合には posZF があらわれる 事を報告している。MR の機能を解明するにあたつて 先ず此の事賽を確めておく必要がある。

-Exp. III-

【目的】 $\mathrm{R}_{1}$ )に先行する地刺战を提示しない場合， ZF が如何にあらわれるかを考察する。

【梣件】 $\left.\mathrm{R}_{(1)}, \mathrm{R}_{2}\right)$ の $\mathrm{DZ}$ (各 2 秒, $\mathrm{R}_{1)}$ と $\mathrm{R}_{(2)}$ の $Z Z$ は 1, 3, 6, 9, 12 秒。此の間は MR で理められる。 後續刺械は $\mathrm{R}_{(2)}$ の2 秒後まで提示した。 $\mathrm{MR}$ 及で後續 刺钱の明るさは Exp. II にお汀万刺钱の明るさと等し い。

[Vp.] Ot, Os, St, Ay の 4 名。

【結聚】表 III の如くである。MR を提示寸る事に 估つて posZF があらわれる。Exp. II において述べた 理由から後續刺戱は問題之しない。

次により明るいMR 分 posZF の生起と如何なる關 聯があるかを MR に關して種々の條件變化を行つて考 察してみよう。その場合, 若干 negZF の間題にも觸九 る事になるであろう。勿論我々の主要テ一マは posZF の解明にあるのだが， posZF が negZF と密接な關聯の 下に1つの ZF を形成している以上, posZF の解明が

表

III

\begin{tabular}{|c|c|c|c|c|c|c|c|c|c|c|c|c|c|c|c|c|c|c|c|c|c|c|c|c|c|}
\hline Vp. & \multicolumn{5}{|c|}{$\mathrm{Ot}$} & \multicolumn{5}{|c|}{ St } & \multicolumn{5}{|c|}{ Os } & \multicolumn{5}{|c|}{ Ay } & \multicolumn{5}{|c|}{ 計 } \\
\hline $\begin{array}{l}\text { 制略 } \\
\mathrm{ZZ}\end{array}$ & $\mathrm{H}$ & $\mathrm{D}$ & & $\mathrm{U}$ & $\mathrm{D} \%$ & $\mathrm{H}$ & D & G & $\mathrm{U}$ & $\mathrm{D} \%$ & $\mathrm{H}$ & D & G & $\mathrm{U}$ & $\mathrm{D} \%$ & $\mathrm{H}$ & $\mathrm{D}$ & G & $\mathrm{U}$ & $\mathrm{D} \%$ & $\mathrm{H}$ & D & $\mathrm{G}$ & $\mathrm{U} / \mathrm{I}$ & $\mathrm{D} \%$ \\
\hline 1 & $5 \mid$ & 19 & 6 & 0 & +47 & 6 & 15 & 9 & 0 & +30 & 2 & 25 & 3 & 0 & $+77^{\prime}$ & 8 & 14 & 8 & 0 & +20 & 21 & 73 & 26 & 0 & +43 \\
\hline 3 & 6 & 16 & 8 & 0 & +33 & 9 & 11 & 10 & 0 & +7 & 8 & 14 & 7 & 1 & +20 & 11 & 14 & 5 & 0 & +10 & 34 & 55 & 30 & 1. & +18 \\
\hline 6 & 5 & 20 & 5 & 0 & +50 & 6 & 21 & 3 & 0 & +50 & 5 & 20 & 5 & 0 & +50 & 5 & 16 & 9 & 0 & $+37^{\prime}$ & 21 & 77 & 22 & 0. & +47 \\
\hline 9 & 5 & 18 & 6 & 1 & +43 & 6 & 22 & 2 & 0 & +53 & 5 & 19 & 6 & 0 & +47 & 5 & 22 & 3 & 0 & +57 & 21 & 81 & 17 & 1 & +50 \\
\hline 12 & 5 & 22 & 3 & 0 & +57 & 5. & 21 & .3 & 1 & +53 & 5 & 16 & 9 & 0 & +37 & 6 & 16 & 7 & 1 & +33 & 21 & 75 & 22 & 2 & +45 \\
\hline
\end{tabular}

表 IV

\begin{tabular}{|c|c|c|c|c|c|c|c|c|c|c|c|c|c|c|c|c|c|c|c|c|}
\hline Vp. & & & Os & & & & & Ot & & & & & St & & & & & 棓 & & \\
\hline 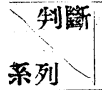 & $\mathrm{H}$ & $D$ & G & $\mathrm{U}$ & $\mathrm{D} \%$ & $\mathrm{H}$ & $\mathrm{D}$ & G & $\mathrm{U}$ & $\mathrm{D} \%$ & $\mathrm{H}$ & D & G & $\mathrm{U}$ & $\mathrm{D} \%$ & $\mathrm{H}$ & D & $\mathrm{G}$ & $\mathrm{U}$ & $\mathrm{D} \%$ \\
\hline$S_{1}$ & 14 & 3 & 7 & 0 & -46 & 16 & 5 & 3 & 0 & -46 & 12 & 7 & 5 & 0 & -21 & 42 & 15 & 15 & 0 & -37 \\
\hline $\mathrm{S}_{2}$ & 12 & 7 & 5 & 0 & -21 & 11 & 8 & 5 & 0 & -13 & 7 & $?$ & 8 & 0 & +8 & 30 & 24 & 18 & 0 & -8 \\
\hline $\mathrm{S}_{3}$ & 10 & 8 & 6 & 0 & -8 & 7 & 15 & 2 & 0 & +33 & 5 & 17 & 1 & 1 & +50 & 22 & 40 & 9 & 1 & +25 \\
\hline
\end{tabular}


必然的に ZF 全般の間題と關聯してくる事は致し方のな い事である。

-Exp. IV-

目的】 $\mathrm{R}_{(1)}$ と $\mathrm{R}_{(2)}$ の間の $Z Z$ を一定にして $M R$ の DZ 学變化し ZF が如何に劣らわ机るかを考察する。

【修件】 $\mathrm{R}_{(1)}$ 及び $\mathrm{R}_{(2)}, の \mathrm{DZ}$ ( 2 秒, $\mathrm{R}_{1)}$ と $\mathrm{R}_{(2)}$ の $Z Z$ は6秒に一定。MR の明るさは Exp. III と等しい MR は $\mathrm{R}_{(1)}$ の直後に提示する。 $\mathrm{MR} の \mathrm{DZ}$ は $\mathrm{S}_{1}$ にお いては1秒。 $\mathrm{S}_{2}$ に抒いては 3 秒。 $\mathrm{S}_{3}$ は 6 秒。

【Vp】 Os, Ot, St の3名

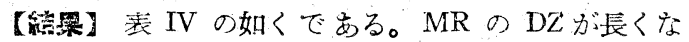
るにつ机て posZF の量が增す。此の結果に對しては 4 .

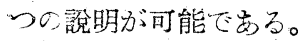

1. 先ず第 1 に $\mathrm{R}_{1}$ ）と $\mathrm{R}_{(2)}$ の間の無刺钱狀態の時 間が長い程 negZF があらわれるのではないかと云う事 が考觉られる。

2. 第 $2 に \mathrm{R}_{1}$ と $\mathrm{MR}$ との閒に同化が括こつたので あると必考光ら机る。气の場合, 同化の量は $\mathrm{MR} の \mathrm{DZ}$ が長くなればなる程塉してゆくと前提す礼ば此の實驗の 結果は說明される。

3. 第3に $\mathrm{MR}$ と $\mathrm{R}_{2}$ ) の間の對比勃果に依つても說 明が可能である。但し此の場合には $M R$ と $R_{(2)}$ の間の 時間的長さが長くなればなる程, 對比效果は弱まると假 定しなくてはならない。さて一般に同化と對比とは別簡 の現畺ではなく兩者は移行的な1つの現象とされている それにも拘らず，此處で同化と對比を分けて考察したの は前者が $\mathrm{R}_{1}$ )と $\mathrm{MR}$ との間の關係を指しているのに反 して，後者が $M R$ と $\mathrm{R}_{2}$ )との間の關係であるからであ る。此の場合，2つを分けて考える事は自明の事である が，混同する恐れがあるので特に注意しておく。以下本 節で對比効果と云う塄合は此の樣な意味で用いる。

4. 神經系內に1つの過程が生じた場合, その過程が 洛了した後にも倘何等かの殘効が殘る事は殆ど疑う余地 がない。神經系に括ける第 1 過程の罣奮つ殘勃が續いて

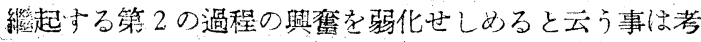
え得る事である。此の樈は効果齐假に制止効果と名付け 上う。此の實驗についてて云えば， $\mathrm{R}_{(2)}$ は $\mathrm{MR}$ の制止効 果によつて暞く見える。しかし $M R$ と $\mathrm{R}_{(2)}$ の时間的長 さが長くなれ版止效果も弱くなるであろう。その結果 $S_{2}$ は $S_{3} よ り$ neg ZF を示し， $S_{1}$ に括いては更に negative となるであろう。かくの如く制止効果によつ
ても此の實騨の結果は說明される。

以上の 4 つの說明が可能であるが，次に我々及は此の 4 つの要因を吟味する篇に，先ず同化，對比の抗こらな

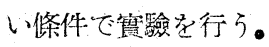

一Exp. V-

【目的] $\mathrm{R}_{(1)}$ と $\mathrm{R}_{(2)}$ の間に $\mathrm{R}_{(1)}$ と同じ明るさの $\mathrm{MR}$ を提示する事によつて ZF が如何にあらわれるが考察 ナる。

【修件】 $\mathrm{R}_{(1)}$ 及的 $\mathrm{R}_{(2)}$ の $\mathrm{DZ}$ は2 秒。 $\left.\mathrm{R}_{1}\right) と \mathrm{R}_{2}$ ， の間の $Z Z$ は 4 秒。 $S_{1}$ に玌いは $M R$ を提示しない。 $\mathrm{S}_{2}$ では中間に $\mathrm{MR}$ を提示。 $\mathrm{MR} の \mathrm{DZ}$ は2 秒。 $\mathrm{R}_{(1)}$ と $M R, M R$ と $R_{(2)}$ のZ 2 は各 1 秒。 $M R$ は $R_{(1)}$ の 明るさと等しい。

[Vp] Os, Ay, Ot, St の 4 名。

【結果】表 V の如くでむる。 $\mathrm{S}_{2}$ において，上り大き な posZF があらわれる。

1. 此の場合, $\mathrm{R}_{1}$ ) と $\mathrm{MR}$ の明ろさは等しいのであ るから，同化及び對比効果では此の兾驗は說明されない。

2. $\mathrm{R}_{(1)}$ と $\mathrm{MR}$ の明るさは客観的には等しいのであ るが，現象的には MR の方が稍㹮く見完る。若し MR の現象的明るさに對し同化或いは對比效果がおこるので あれば $S_{2}$ は僅かでもより neg ZF を示す䈍である。何 れにしても同化及び對比効果は此の簀驗の結果を說明す る事は出來ない。

3. $\mathrm{S}_{1}$ に怙いては $\mathrm{R}_{1}$ )と $\mathrm{R}_{(2)}$ の間の無刺战狀態ひ 時間は 4 秒であり， $S_{2}$ に执いては 2 秒である。 $R_{1}$ ) と

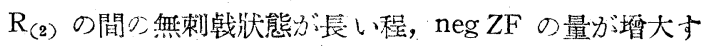
ると云う說明は此處でも妥當する。

4. MR の制止效果に依り $\mathrm{R}_{(2)}$ 少䐺く見穴て $\operatorname{pos} Z \mathrm{~F}$ が劣らわれたと考える事も可能である。

次に $\mathrm{R}_{(1)}$ と $\mathrm{R}_{(2)}$ の閒の無刺㦸狀態の時間を一定に して富羷を行ら。

-Exp. VI-

【目的】 $R_{(1)}$ と $\mathbf{R}_{(2)}$ の間の $Z Z$ を一定にし，MRの 時間的位置省變化して ZF が如何にあらわ礼るかを考察 する。

【條件】 $\mathrm{R}_{1)}$ 及支び $\mathrm{R}_{(2)}$ の $\mathrm{DZ}$ は各2 抄。 $\mathrm{R}_{(1)}<\mathrm{R}_{(2)}$ の間の $Z Z$ は 9 秒に一定。 $\mathrm{S}_{1}$ に扔いては $\mathrm{R}_{(1)}$ の直後に $M R$ 提示。 $S_{2}$ に怙いては $R_{(1)}$ と $R_{(3)}$ の中間に提示 ( $\mathrm{R}_{(1)}$ と $\mathrm{MR}$ ，MR と $\mathrm{R}_{(2)}$ の ZZ は各 3 秒)。 $\mathrm{S}_{3}$ に 颃いては $\mathrm{R}_{2}$ ，の直前に $\mathrm{MR}$ を提示。 $\mathrm{MR}$ の $\mathrm{DZ}$ は

$\mathrm{V}$

\begin{tabular}{|c|c|c|c|c|c|c|c|c|c|c|c|c|c|c|c|c|c|c|c|c|c|c|c|c|c|}
\hline Vp. & \multicolumn{5}{|c|}{ Os } & \multicolumn{5}{|c|}{ Ay } & \multicolumn{5}{|c|}{ Ot } & \multicolumn{5}{|c|}{ St } & \multicolumn{5}{|c|}{ 計 } \\
\hline 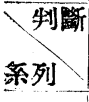 & $\mathrm{H}$ & $\mathrm{D}$ & $\mathrm{G}$ & $\mathrm{U}$ & $\mathrm{D} \%$ & $\mathrm{H}_{1}$ & $\mathrm{D}$ & $\mathrm{G}$ & $\mathrm{U}$ & $\mathrm{D} \%$ & $\mathrm{H}$ & $\mathrm{D}$ & G & $\mathrm{U}$ & D\% & $\mathrm{H}$ & D & G & $\mathrm{U}$ & $\mathrm{D} \%$ & $\mathbf{H}$ & D & G & $\mathrm{U}]$ & D \\
\hline $\mathrm{S}_{1}$ & 7 & 9 & 8 & 0 & +8 & 9 & 9 & 6 & 0 & 0 & 17 & 7 & 0 & 0 & -42 & 8 & 11. & 5 & 0 & +13 & 41 & 36 & 19 & 0 & -5 \\
\hline $\mathrm{S}_{2}$ & 6 & 15 & 3 & 0 & +38 & 4 & 15 & 5 & 0 & +46 & 13 & 10 & 1 & 0 & -13 & 4 & 14 & 6 & 0 & +42 & 27 & 54. & 15 & 0 & +28 \\
\hline
\end{tabular}


表

\begin{tabular}{|c|c|c|c|c|c|c|c|c|c|c|c|c|c|c|c|c|c|c|c|c|}
\hline \multirow{2}{*}{$\begin{array}{c}\text { Vp. } \\
\text { 制斷 } \\
\text { 系列 }\end{array}$} & \multicolumn{5}{|c|}{ Ot } & \multicolumn{5}{|c|}{$\mathrm{Ay}$} & \multicolumn{5}{|c|}{ Os } & \multicolumn{5}{|c|}{ 計 } \\
\hline & $\mathrm{H}$ & $\mathrm{D}$ & G & $\mathrm{U}$ & $\mathrm{D} \%$ & $\mathrm{H}$ & D & G & U & $\mathrm{D} \%$ & $\mathrm{H}$ & D & G & U & $\mathrm{D} \%$ & $\mathrm{H}$ & D & G & U & $\mathrm{D} \%$ \\
\hline$S_{1}$ & 12 & 7 & 4 & 1 & -21 & 8 & 9 & 7 & 0 & +4 & 9 & 10 & 5 & 0 & +4 & 29 & 26 & 16 & 1 & -4 \\
\hline $\mathrm{S}_{2}$ & 15 & 7 & 2 & 0 & -33 & 9 & 6 & 9 & 0 & -13 & 13 & 8 & 3 & 0 & -21 & 37 & 21 & 14 & 0 & -22 \\
\hline$S_{3}$ & 7 & 14 & 2 & 1 & +27 & 6 & 12 & 6 & 0 & +25 & 5 & 13 & 6 & 0 & +33 & 18 & 39 & 14 & 1 & +29 \\
\hline
\end{tabular}

$\mathrm{S}_{1}, \mathrm{~S}_{2}, \mathrm{~S}_{3}$ すべて3秒。 MR の明るさは Exp.IV.に等 LW $(M R>N)$

【Vp】 Ot, Ay, Os の 3 名。

【絬亚】表 VI の如くである。 $\mathrm{S}_{2}$ に招いて neg ZF の量は最大。 $\mathrm{S}_{\mathbf{3}}$ に扮いて pos ZF の量が最大となる。

1. 此の兾驗では $R_{(1)}$ と $R_{(2)}$ の間の無刺戱狀態の 時間は 3 采列共 6 秒である爲，無刺钱の要因は問題にな らない。

2. 若し同化のみが ZF を規定する因子であるならば

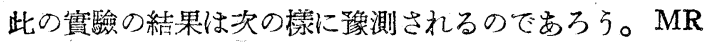
が $\mathbf{R}_{(1)}$ の直後に提示された時， $\mathbf{R}_{(1)}$ と $\mathrm{MR}$ の同化量 は最大で, $\mathrm{R}_{(1)}$ と $\mathrm{MR}$ の $\mathrm{ZZ}$ が長くなるに從つて, $\mathrm{E}_{(1)}$ と MR の同化量は減ずるであろ弓。郎ち $\mathrm{S}_{1}$ にお いて最大の pos ZF があらわれ， $S_{3}$ に怙いて最大の neg ZF があらわれる。此の樣な豫测をするには，2過程の 同化量はその時間的距離に反比例して太きくなると云う 事が前提となつているが，此の前提は同化說にとつて決 して無理なものではないであろう。

所が同化說による以上の樣な豫測は，實驗結果に合致 しない。 $S_{2}$ が $S_{1}$ よりも neg ZF を示寸事は同化說の 矠测通りであるが， $S_{3}$ は逆に最大の pos ZZFを示して いる。

3. 次に我々は制止効果について呤味しなけれればなら ない。Exp.IV に打いて，MR の制止効果は $M R$ とR(2) の ZZが增大するにつれて減じてゆくとなしたが此處で るその前提の上に立つて，此の實驗を見るならば， $\mathrm{S}_{3}$ に执いて最大の pos ZF， $S_{1}$ において最大の neg ZF が あらわれなければならない筈である。しかしながら實驗 結果は上述の如くである。

4. 前二項の考察から，此の筫驗結果を矛盾なく說明 する䉆には同化の要因及び制止効果の兩者を共に容認し なければならないと云う事が結論される。刨ち MR が $\mathbf{R}_{(1)}$ の直後にある時は制止効果は微弱であるが，同化の 要因は强力で pos ZF があらわれる。文 $\mathrm{MR}$ が $\mathrm{R}_{(2)}$ の 直前にある時は同化の要因は殆ど働かないが制止効果に 低つて pos ZF があらわれる。 $\mathrm{S}_{2}$ では同化，制止效果 共に强く働かない篇に，より大きいneg ZF があらわれ たのであると考えられる。

5. 前項と同荄の論法を以て，同化の要因と對比効果 の兩者によつて此の實驗の結果を說明する事も可能であ る。
以上で本節の 4 實驗を終るが，次に ZF を規定する因 子として我々の想定した 4 つ要因について考察する。

(1) 無刺战の要因について。 $R_{(1)}$ と $R_{(2)}$ の間の無刺 战狀態の長さが長い程 neg ZF の量が增大寸ると云う事 實は，かなり廣範な實殮結果に見ら机る所である。さて 比較に和汁る無刺戲狀態の機制に關しては Pratt (11) と Lauenstein $(6,7)$ との $2 つ の$ 學說がある前者では, 無刺战狀態の痕跡はあり得ないとして，痕跡は隣接する 無刺裁狀態に對しては沈下 (sink) すると考える。後者 では，痕跡は無刺㦸狀態に對して同化すると考える。二 者何れが正しいか我々の實䛗から決定的な斷定を下寸事 は出來ないが，此處では次の 4 つの理由から後者をとり

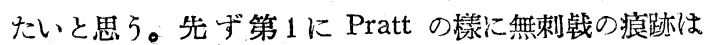
無いと考えるのはあまりにも形式論理的である。それは あたかも Aristoteles が㙺空は無なるが故に存在せずと 考えた樣に，形而上學的な論理である。第 2 に Pratt の 考え方には無刺战狀態と有刺战狀態とがはつきり區分さ れる事が前提となつているが，現象的には兩者の限界點

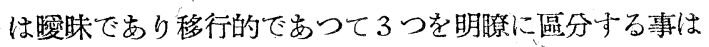
出來ない。第 3 に無刺戲は Nichts ではなく，やはり知 覺されたあるものである。此の事からも無刺敦紎態と有 刺战狀態とを區別寸る事は正しくない。第4 亿圓の大き さの繼時比較に怙ける同化對比現象について佐藤氏 $(12)$ が實驗を行つているが，その結果は大體に离いて無刺钱 狀態は圓の極大極小的なるのとして考穴られる。以上の 理由によつて，Lauenstein の同化說をとる。そうする と無刺戱の要因は同化說に包括され，特に取出子必要は なくなる。以上は $\mathbf{R}_{(1)}$ が無刺战狀態に瞵接している場 合の事であるが， $R_{(1)}$ が直接無刺戱狀態に隣接していな い場合にも $\mathrm{R}_{(1)}$ と無刺钱狀態が同化するのであるかと 云う事が疑問になるであろう。邲ち相隔る痕跡間にも同 化が执こるかと云う事になるが，それについてはすでに Lauenstein が中心傾向を論ずるに當つて先行刺钱群の同 化による Niveau を假定して居り，此の假定を認める以 上な相隔る痕跡の同化も容認しなくてはならない。上述

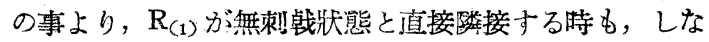
い時も無刺战の要因は同化說に包括されると考えて差任 えないであうう。

(2) 對比効果について。此處で云万對比效果とは MR と $\mathrm{R}_{2}$ ) の間に执こるものを意味する事は既述の如くで ある。からる意味に打ける對比效果には2つの意味があ 
る。1つは記述概念としての對比效果で劣る。 $R_{(1)}$ と $\mathbf{R}_{2}$ ）間により明るい $M R$ が提示された場合の比較制 斷の現象を記述すると次の如くである。 $\mathbf{R}_{(1)}$ の後により 明るい $\mathrm{MR}$ を知覺する。次に $\mathrm{R}_{(2)}$ が提示されると $\mathrm{MR}$ と、 $\mathbf{R}_{(2)}$ の勾配が知覺され，暗いと云う判㫁に似たもの が生ずる。それと同時に $R_{(1)}$ と $R_{(2)}$ の勾配が知覺さ れるが，MR と $\mathrm{R}_{(2)}$ の勾配知覺及びそれに續く暗いと 云ら感じがより vivid であり直接的である篇，その感じ が基調となり暗いと云う判斷が生ずる。此の㟫な形式て 制斷が生じた場合，對比効果がおこつたと云う。之が第 1の意味に打ける街比効果である。か〉る記述概念とし ての對比效果は否定する事が出來ない。內觀的事實とし て，本論交に抢ける實驗においてもしばしば報告された からである。しかしながら我々の目的は現象の單なる記 述にあるのではなくして，現象の奥にひそむ椹能を探究 するになる。ZF を規定する因子も又，機能概念でなけ ればならない。それ故記述概念としての對比効果は ZF を規定する因子より除外しよ5と思う。しかしながら對 比效果は機能概念として用いられる事がある。例えばい わゆる同化對比と稱される場合がそれである。我々の實 驗に抬いてもその樣な意味における對比がおこつたので はないかと云う事が考えられるであるう。此の問題に關 しては更に次節の實驗を俟つた上で考察したい。

(3) 同化について。Exp. VI の結果は先ず第1にZF を規定する因子として同化を舉げなければならないと云 万事第2 にその同化は $\mathrm{R}_{(1)}$ と MR との間の機能的聯 關である事，第 $3 に M R$ と $R_{(2)}$ との機能的聯關とし て對比效果か或いは制止効果を考否に入れなければなら ない事一一此の3つの事䨘を示唆する。先づ第1の點は, 彗刺战の要因を同化說が包括すると考える時，今までの 我々のナべての賽簽が之を支持する。第 2 の黣は特に目 新しい事宦ではない。同化證を唱える者はすべて，同化

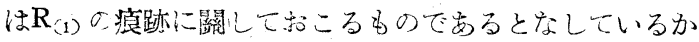
らで要る。第3の點は今まで看過されてきた重珼である が對比効果についてはすでに前項で述べ，制止効果に關 しては次項で考察するから，此處では同化以外にも ZF を規定打因子の要る事を注意するにとがめておく。

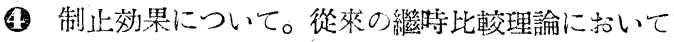
は專ら第 1 過程の痕跡の;變容の久が問題となり，第 2 過 程が第 1 過程の殘効によつて變容する事は等閶視されて きたうらみがある。先ず從來の比皎理論及び $Z F$ 理論 を一瞥しよう。今對象 A，B が比較意圖の下に繼特的 に把捉されたとする。A，Bの知鹠に對潐寸る心理物理 的過程 $a, b$ は同一の場所に相次いで經過するであろう その際 a はその經過せる場所に僅かにその檿を異にし て痕跡を殘し，b は a の經過せる同一の場所，同一の 磻に a に續いて經過する。 b と a の痕跡は統一的全體 過程に體制化される。そしてそれは一定の構浩特質を持 む，之が比較印象の基礎となる。 $\mathrm{A}$ と B が客觀的に等
しい刺钱である時 ZF があらわれるのは，痕跡、a が同 化, gestaltmässig に作用与る力, 解溶 (Auflösung) 等 によつて變容するからである。比㖫過程及び ZF は此の 樣に考えられてきた $(1,6,7)$ 。郎ち $Z F$ は第 1 過程の 痕跡の變容のみによつて證明さ札てきた。しかしながら 第 1 過程の殘效が第 2 過程を變容せしめる事は，例穴ば Gibson 效果 $(2,3)$ や Köhler 效果 (4) に上つて明ら かであり，之を否定する事は出來ない。ZF 理論に劣い。 ても之を無視する事は許されないであろう。今說明の便 宜上, 痕跡累曆の假說の圖式（此の圆式を利用したのは 制止効果の理解に便であろ弓と思つたからである。痕跡

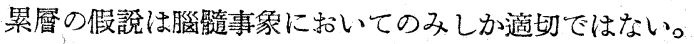
然るに此の䔈羷にひき續き行つた實驗に依り制止効果の 生理學的局所は大腦に限定されない事を示す1つの根據 を得る事が出來た。それ故，此の㘣式は全く便宜的なむ のと解されたいによよてからる殘効を說明すると次の 樣になる (涪參照) 前と同じく比較對象 $\mathrm{A}, \mathrm{B}$ の心理物
(I)

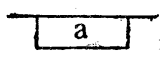

(II)

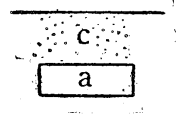

圖

I
(III)

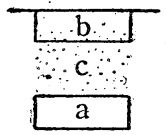

理的過程を a,b とする。第 1 の比較對象は神經系に何 等かの過程を生ぜしめるであろう（i)。aは時間の經過 と共に曆を異にする（ii）。その際a は次に繼起する現 實の知覺過程に對しても効果を及ぼすと考えられる。a が效果を及ばす領域を c としよう。次に B が知覺され b なる過程が生ずる（iii）。若し此の時 b が c 領㖪內 にあるならば b はその効果によつて變容する。

さて，上述の如き第 2 過程を變容せしめる第 1 過程の 残効の1つとして制止效果を考えたのである。之を制止 効果と名付けたのは, 明るさの繼時比較に颃いては, 神 經系內の第 1 過程の興崔の殘効が第 2 過程の與奮を制止 して弱化せしめ，その結果，現象的には暗く見完ると考 えられるからである。（音强度，重量等の繼時比較に心 いても類似の效果が認められる檬で要る。しかし勿論第 2 過程の綌签をもたらす殘効は制止効果のみではない。 例えば圖形の繼特比較に预いては別種の效果を想定しな ければならないであ万弓）本節における我々の賽驗結果 は制止效果の存在を肯定するものであるが，そ机は更に 內觀によつても確認される。Exp II に拉いて $\mathrm{R}_{(1)}$

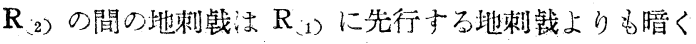
見えた。灭Exp. $V$ では $M R$ と $R_{1}$ )の客觀的明るさは 等しいにも拘らず，MR の方が暗く見えた。此の內観的

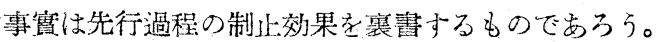

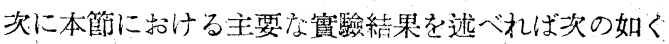
である。

1. $\mathrm{R}_{(1)}$ と $\mathrm{R}_{(2)}$ の間を埋めるより明るい $\mathrm{MR}$ が提 
宗されるる時は $\operatorname{pos} Z \mathrm{~F}$ 加出らわれる。

2. MR の機能として

i. $M R$ と $R_{1}$ ）の間には同化が岕こる。

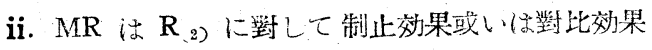
定持つ。

3. 故に1.に批いて云われた MRによる $\operatorname{pos} 2 \mathrm{~F}$ は $M R$ と $R_{1}$ ) との同化及び $M R$ の $\mathrm{R}_{(1)}$ に對する制止効 果或いは對比効果によるものである。

\section{V より明るい地刺戟と陽性時問錯誤 $[\mathrm{II}]$ 一一先行欶㦸について}

本節ではより明るい地刺钱の中 VR が ZF に如何に 影響するかを考察する。

-Exp VII-

【层的】より明るいVRを提示する事に依り ZF が 如何にあらうれるかを考察する。

【燐件】 $\mathrm{R}_{1}$ ) 及び $\mathrm{R}_{2}$ )の $\mathrm{DZ}$ は各 2 秒。 $\mathrm{R}_{1}$ と $\mathrm{R}_{2}$ ) の間の $Z Z$ は3秒。 $\mathrm{S}_{1}$ はVRなし。 $\mathrm{S}_{2}$ に侊いては $\mathrm{R}_{(1)}$ の运前に VR を提示する。VRの DZ は4秒 VRの

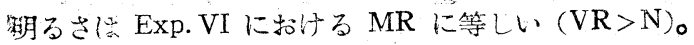

$\mathrm{Vp}$ : Os, M, Ay, St の4名。

【結壆】荠 VII の如くである。VR がある場合はよ り大きい neg ZF があらわれる。

1. VR と $\mathrm{R}_{1}$ ) の間に同化が扢こつたとするならば

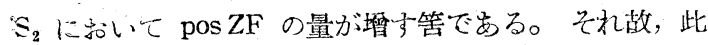
處ではVR と $\mathbf{R}_{(1)}$ の間に同化が括こつたと云う事は考

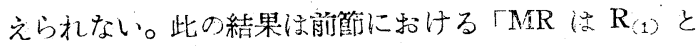
同化する」と云う結論と一見䂆盾している感與える。 同化を当つて單純に 2 過程間におこる現象とするならば 此の實羷結果は明らかに前簀のそれと背反するものであ る。しかし此の矛盾は次の樣に考える事によつて解決子 る。VR と MR は本質的にその性格を異にしている。 VR は比較すべき刺钱の前に提示されるものであり， MR は中間に提示されるものである。2つの比較對象が

衰

\begin{tabular}{|c|c|c|c|c|c|c|c|c|c|c|c|c|c|c|c|c|c|c|c|c|c|c|c|c|}
\hline Vp. & \multicolumn{5}{|c|}{ Os } & \multicolumn{5}{|c|}{$\mathrm{M}$} & \multicolumn{5}{|c|}{ Ay } & \multicolumn{5}{|c|}{$S t$} & \multicolumn{4}{|c|}{ 計 } \\
\hline $\begin{array}{l}\text { 修斷 } \\
\text { 棌列 }\end{array}$ & $\mathrm{H}_{1}^{\prime}$ & $\mathrm{D}$ & G & U & D do & $\mathrm{H}$ & $\mathrm{D}$ & G & $\mathrm{U}$ & $\mathrm{D} \%$ & $\mathrm{H}$ & $\mathrm{D}$ & G & $\mathrm{U}$ & $D \%$ & $\mathrm{H}$ & $\mathrm{D}$ & $\mathrm{G}$ & $\mathrm{U}$ & $D \%$ & $\mathrm{H}$ & D & $\begin{array}{lll}G & L\end{array}$ & $\mathrm{U} D \%$ \\
\hline $\mathrm{S}_{1}$ & & 7 & 5 & 0 & -21 & 9 & 12 & $\begin{array}{l}3 \\
5\end{array}$ & 0 & $\begin{array}{l}+13 \\
-13\end{array}$ & $\begin{array}{r}8 \\
12\end{array}$ & $\begin{array}{l}9 \\
9\end{array}$ & $\begin{array}{l}7 \\
3\end{array}$ & $\begin{array}{l}0 \\
0\end{array}$ & $\begin{array}{l}+4 \\
-13\end{array}$ & $\begin{array}{l}4 \\
7\end{array}$ & $\begin{array}{r}10 \\
8\end{array}$ & $\begin{array}{l}9 \\
9\end{array}$ & $\begin{array}{l}1 \\
0\end{array}$ & $\begin{array}{l}+25 \\
+4\end{array}$ & $\begin{array}{l}33 \\
44\end{array}$ & $\begin{array}{l}38 \\
32\end{array}$ & $\begin{array}{l}24 \\
20\end{array}$ & \begin{tabular}{l|l}
1 & +5 \\
0 & -13
\end{tabular} \\
\hline$S_{2}$ & 14 & 7 & 3 & 0 & -29 & 11 & 8 & 5 & 0 & $|-13|$ & 12 & 9 & 3 & 0 & -13 & 7 & 8 & 9 & 0 & & & & & \\
\hline
\end{tabular}

衰 VIII

\begin{tabular}{|c|c|c|c|c|c|c|c|c|c|c|c|c|c|c|c|c|c|c|c|c|c|c|c|}
\hline Vp. & & & $\mathrm{O}$ & & & & & St & & & & & Ot & & & & M & & & & & 部 & \\
\hline 制断 & $\mathrm{H}$ & $\mathrm{D}$ & G & $U$ & $\mathrm{D} \%$ & $\mathrm{H}$ & D & G & $\mathrm{U}$ & $\mathrm{D} \%$ & $\mathrm{H}$ & D & G & $\mathrm{U}$ & $D \%$ & $\begin{array}{ll}H^{H} & D\end{array}$ & $G$ & $\mathrm{U}$ & $\mathrm{D} \%$ & $\mathrm{H}$ & D & $\mathrm{G} \mathrm{U}$ & U $D \%$ \\
\hline $\begin{array}{l}S_{1} \\
S\end{array}$ & 11 & 9 & 4 & 0 & $\left|\begin{array}{l}-8 \\
-42\end{array}\right|$ & 6 & 8 & 8 & 2 & $\begin{array}{l}+8 \\
-17\end{array}$ & 11 & $\begin{array}{l}6 \\
8\end{array}$ & 4 & $\begin{array}{l}3 \\
0\end{array}$ & $\begin{array}{l}-21 \\
-33\end{array}$ & $\begin{array}{rr}9 & 10 \\
12 & 8\end{array}$ & $\begin{array}{l}5 \\
4\end{array}$ & $\begin{array}{l}0 \\
0\end{array}$ & $\begin{array}{l}+4 \\
-17\end{array}$ & $\begin{array}{l}37 \\
55\end{array}$ & \begin{tabular}{l|}
33 \\
29
\end{tabular} & \begin{tabular}{c|c}
21 & 5 \\
12 & 0
\end{tabular} & \begin{tabular}{l|l}
5 & -4 \\
0 & -27
\end{tabular} \\
\hline $\mathrm{S}_{2}$ & 16 & 6 & 2 & 0 & $-42 \mid$ & 11 & 7 & 6 & 0 & $|-17|$ & 16 & 8 & 0 & 0 & -30 & 128 & 4 & 0 & -11 & & & & $0-27$ \\
\hline
\end{tabular}




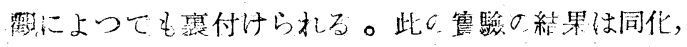

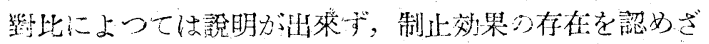
る走得ないであう。

2. さて, 牫々は前節に出いて機能概念としての, 對比 に關する閒題名殘してきたが，此處で前篩の實驗も考慮 うのは第 1 の過程が第 2 の過程を對比的心變容せしめる 場合の事索云う(これは前節で用いた意味での對比効果

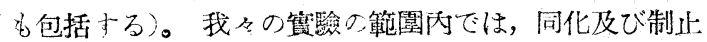
效果名之を㤎めなけ玌ばならない賽驗結果 (Exp. VI, Exp. VIII，が存在才るにも拘わらず，對比効果はそれ をもたない。對比效果によつて說明し得る霬羷結果はす ベて制止効果によつて子說明し得るので岀る。それに反 して制止効果によつて說明し得る鼻驗結果は必ずしも對 比效果によつては證明出來ない。名〉る場合，我々の嘪 䀫に關子る限り，ZF 学規定する因子から對比効果を除 外しても誤りではなからう。ZF が多くの因于の合成の

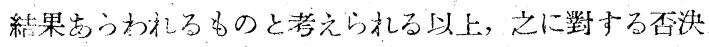

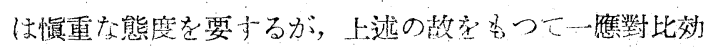
果法考慮の外心叔てもよいと思亏。

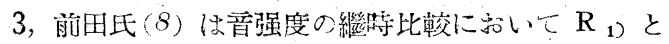

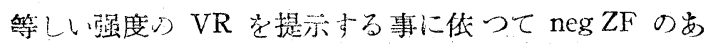
らわれる事を報告している。此の事筫は我々の實礆結果 と符合小る。

-Exp. IX-

[日的】VR の時間的位置を變化する事によつて ZF

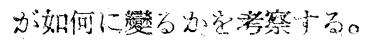

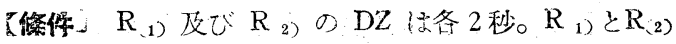
の $\mathrm{ZZ}$ は 1 秒に一定。 VR の $\mathrm{DZ}$ は秒。VRの蓦る 织 Exp. VII と等しい $(V R>N)$ VR と $R_{1} ， の Z Z$ は $\mathrm{S}_{1}$ に这いては0秒。 $\mathrm{S}_{2}$ では秒。 $\mathrm{S}_{3}$ では6秒。

[Vp: Os, Ay, Ot の3名

【結繁] 表 IX の如くである。VRとR $\mathrm{R}_{1}$ )のZZ か 長くなるに從つて, neg ZF の量が減ずる。我々は Exp. IV に出いて MR の制止效果は MR と $\left.R_{2}\right)$ DZ が 長くなるにつ机て，微弱になる事を假定してきた。若し 此の假定が正しいならば，VR の場合にも同橙の事が云 われるでまろち。即ち VR む提示した場合は， $\mathrm{R}_{(1)}$ が暗 く是光， negZF があらわれるのであるが，VR と $\mathrm{R}_{(1)}$ の ZZ ぶ長くなれば VR の制止効果は微弱となり neg にい扎て, 此の問題を考察しよう。此處て對比效果と云

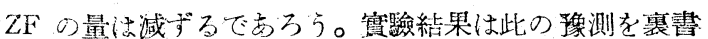
する。つまり 1つの過程の持つ制止效果は時間の經過と 其に微弱になるのでらる。

本節における主要け實驗結果は次の如くである。

Dより明るいVR を提示子ると neg ZF があらわ 礼方。

$2 \mathrm{VR}$ は $\mathrm{R}_{(1)}$ に斨して制止効果圭持つ。

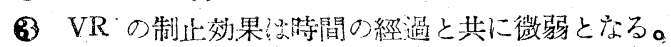

\section{VI 時間々㯨の短い場合に於ける 陽性時間錯誤}

前節に怙いて我々は地剌战がより明るい場合つ posZF について考究してきた。の結果，從來の $\mathrm{R}_{1}$ ) と地剌 战との同化によつてのみ說明されてきた理論では不供て 古り，先行過程の残效によつて $\mathrm{R}_{2}$ )が制止的に變容子

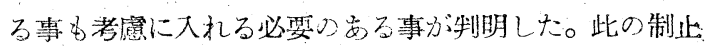
效果こそ ZZ 方短い時の $\cos Z F$ を解明する鍵ではなか

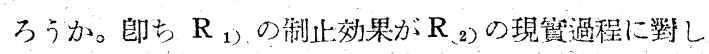
て作用する事に依つて，現象的には $\mathrm{R}_{2}$ ) はより暗く見 它て此處に pos ZF が生起する。それでは ZZ が長くな

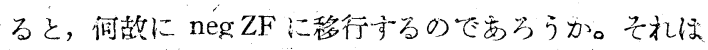
先行過程の制比効果少洔間の經過と共に微弱に方る事, 及び光行過程に隣接する無刺㦸狀態との同化によつて烷

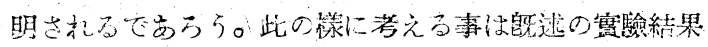
と矛盾しないばかりでなく積極的に支持されるてたるらう 本論文の署頭に乱いて我々は pos ZF 0生起する主要な

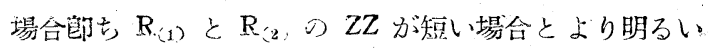

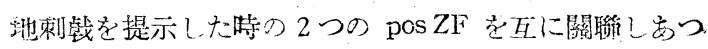
た一元的理諭によつて誈明する事を意團するものである 事を述べた此處に晾いて，我々の目的と寸る pos ZF 理論尖一應確立されたのでする。

さて，我々は上述の樣に $R_{(1)}$ が $R_{2}$ )に對して制止效 果を持つとなしたので㐌るが，そ礼では $\mathrm{R}_{(1)}$ の制止效

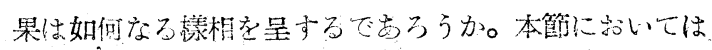
此の開題について若干考察を加えたいと思ら。

-Exp. X-

【目的】 $R_{(1)}$ の $\mathrm{DZ}$ 学變化して ZF が如何に變るか を考察市っ。

【修化】 $\mathrm{R}_{(2)}$ の $\mathrm{DZ}$ は2秒。 $\mathrm{R}_{(1)}$ と $\mathrm{R}_{(2)}, の \mathrm{ZZ}$ は IX

\begin{tabular}{|c|c|c|c|c|c|c|c|c|c|c|c|c|c|c|c|c|c|c|c|c|}
\hline \multirow{2}{*}{$\begin{array}{c}\text { Vp. } \\
\text { 物镐 } \\
\text { 系列 }\end{array}$} & \multicolumn{5}{|c|}{ Os } & \multicolumn{5}{|c|}{ Ay } & \multicolumn{5}{|c|}{ Ot } & \multicolumn{5}{|c|}{ it } \\
\hline & $\mathrm{H}$ & D & $\mathrm{G}$ & $\mathrm{U}$ & $\mathrm{D} \%$ & $\mathrm{H}$ & $\mathrm{D}$ & G & U & $D \%$ & $\mathrm{H}$ & $\mathrm{D}$ & G & $\mathrm{U}$ & $\mathrm{D} \%$ & $\mathrm{H}$ & D & G & $\mathrm{U}$ & $\mathrm{D} \%$ \\
\hline$S_{\text {. }}$ & 16 & 8 & 6 & 0 & -27 & 12 & 10 & 8 & 0 & -7 & 17 & 4 & 8 & 1 & -43 & 45 & 22 & 22 & 1 & -26 \\
\hline $\mathrm{S}_{2}$ & 12 & 11 & 7 & 0 & -3 & 10 & 12 & 8 & 0 & +7 & 16 & 8 & 6 & 0 & -27 & 38 & 31 & 21 & 0 & -8 \\
\hline$S_{8}$ & 12 & 12 & 6 & 0 & 0 & 10 & 10 & 10 & 0 & 0 & 12 & 9 & 7 & 2 & -10 & 34 & 31 & 23 & 2 & -3 \\
\hline
\end{tabular}


3 秒に一定。 $R_{(1)}$ の $D Z$ は $S_{1}$ に扔いては 2 秒， $S_{2}$ で は 4 秒， $\mathrm{S}_{\mathbf{3}}$ では 6 秒である。

[Vp] M, St, Os の3名

【結果】表 $\mathrm{X}$ の如くである。 $\mathrm{R}_{(1)}$ の $\mathrm{DZ}$ が長くなる に從つて pos ZF の量が暼大寸る。

1. 之は $\mathrm{R}_{(\mathbf{1})}$ の $\mathrm{DZ}$ が長くなるに從つて $\mathrm{R}_{1)}$ の制 止効果がより强く作用するる事を示している。

2. $\mathrm{R}_{1}$ )の $\mathrm{DZ}$ が長い時 $\left\ulcorner\mathrm{R}_{(1)}\right.$ が見ている中にだん だん曋くなつてゆく」と云ら內篗報告を得た。之はGibs on 効果 (2) に顿いて刺载持續視中に知覺內容力゙緗容し てゆくと云う事實と種類を同じくするものである。か る現象は何故に生ずるのであろろか。大體, 持續視中に 知覺內容の變容があらわれるのは，刺䖗の $\mathrm{DZ}$ がある程 度以上に長い場合に限られる。即ち刺钱力゙時間的幅を持 つている場合である。かつる場合には 1 つの連續的過程 を前過程（痕跡或いは準痕跡となつた過程）と後過程(現 實の知覺過程）とに分けて考える事が可能である。（勿 理論諭的に分ける事が可能なのであつて，實際に前過程 と後過程との間に境界線があるわけではない）そして前 過程は何等かの殘効を殘し後過程を變容せしめる。その 結果, 刺戱持續視中の知覺內容の變容と云う現象があら われる。我々の場合で云えば, 前過程が後過程に對して は制止効果を持ち，その雼に，客観的には定常的な刺钱 が「だんだん暗くなつてゆく、樣に見えるのである。此の 樣に考えれば，その機制は第 1 過程の殘効が第 2 過程を 變容せしめる場合と全く同樣である事は明らかである。

3. 佾, 此の實驗の結果は和田氏（14）のそれとも一 致するものである。

-Exp. XI-

【目的】 $\mathrm{R}_{(1)}$ の $\mathrm{DZ}$ が長い特， $\mathrm{R}_{(1)}$ と $\mathrm{R}_{2}$ )の $\mathrm{ZZ}$ 變化する事によつて ZF が如何に變るかを考察する。
【條件】 $\mathrm{R}_{(1)}$ の $\mathrm{DZ}$ は 8 秒。 $\mathrm{R}_{(2)}$ の $\mathrm{DZ}$ は 2 秒。 $\mathbf{R}_{(1)}$ と $\mathrm{R}_{(2)}$ の $\mathrm{ZZ}$ は 1, 3, 6, 9 秒。

【Vp】 Ot, Ay, Os の3名

【結果】表 XI の如くである。 $\mathrm{R}_{1}$ )の $\mathrm{DZ}$ が2秒で ある Exp. I と比較すると, Exp. I では無記點 (indi-

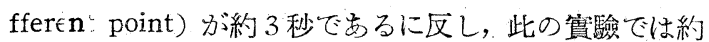
6 秒である。之は $\mathrm{R}_{1}$ )の $\mathrm{DZ}$ が長いと制止効果も長時 間作用する事を意味する。

本節に打ける賽驗結果を概括すると次の如くである。

$\mathrm{R}_{(1)}$ の $\mathrm{R}_{(2)}$ に對する制止効果は， $\mathrm{R}_{(1)}$ の $\mathrm{DZ}$ が長 い程，强く且長時間作用卞る。

\section{VII 結 論}

以上，我及は明るさの繼持比較に於ける陽性時間錯誤 に就いて教察してきたのであるが，本論文の實驗結果を 概括する事によつて結論に替えたい。

明るさの繼時比較に於いては，

(1)時間々隔が短い時の陽性時間錯誤に就いて。第 1 刺战は第 2 刺战に對して制止効果を持つ。その篇，第 2 刺戲は現象的に上り暗く見之，陽性時間錯諨があらわれ る。

(2. 地刺战がより明るい時の陽性時間錯誤に就いて。 先行刺战は第 1 刺战を制止し，第 1 刺钱は中間刺战と同 化する。更に中間刺戱は第 2 刺战を制止する。後續刺唕 は比較判斷にとつて，即ら㭙間錯誤にとつて本質的意義 を持たない。その結果，陽性時間錯誤があらわれる。

B 制止效果は次の樣な性質を持つ。

i. 第 1 過程の刺戲提示時間が長くなれば，第 2 過 程に對する制止効果子强く，且長時間作用する。

ii. 第 1 過程の第 2 過程に對寸る制止効果は第 2 過 程との時間々隔办長くなるに從つて微弱になる。

$\mathrm{x}$

\begin{tabular}{|c|c|c|c|c|c|c|c|c|c|c|c|c|c|c|c|c|c|c|c|c|}
\hline Vp. & \multicolumn{5}{|c|}{ M } & \multicolumn{5}{|c|}{ St } & \multicolumn{5}{|c|}{ Os } & \multicolumn{5}{|c|}{ 計 } \\
\hline $\begin{array}{l}\text { 制粰 } \\
\text { 系列 }\end{array}$ & $\mathrm{H}$ & D & G & U & $\mathrm{D} \%$ & $\mathrm{H}$ & D & $\mathbf{G}$ & U & $\mathrm{D} \%$ & $\mathrm{H}$ & D & G & U & $\mathrm{D} \%$ & $\mathrm{H}$ & D & G & U & $\mathrm{D} \%$ \\
\hline$S_{1}$ & 9 & 10 & 5 & 0 & +4 & 7 & 9 & 8 & 0 & +8 & 14 & 7 & 3 & 0 & -29 & 30 & 26 & 16 & 0 & -6 \\
\hline $\mathrm{S}_{2}$ & 7 & 14 & 3 & 0 & +29 & 5 & 8 & 11 & 0 & +13 & 9 & 9 & 6 & 0 & 0 & 21 & 31 & 20 & 0 & +14 \\
\hline $\mathrm{S}_{3}$ & 5 & 12 & 7 & 0 & +29 & 4 & 12 & 8 & 0 & +33 & 7 & 13 & 4 & 0 & +25 & 16 & 37 & 19 & 0 & +29 \\
\hline
\end{tabular}

表

XI

i. -

\begin{tabular}{|c|c|c|c|c|c|c|c|c|c|c|c|c|c|c|c|c|c|c|c|c|}
\hline Vp. & \multicolumn{5}{|c|}{ Ot } & \multicolumn{5}{|c|}{ Ay } & \multicolumn{5}{|c|}{ Os } & \multicolumn{5}{|c|}{ 計 } \\
\hline $\begin{array}{c}\text { 判斷 } \\
Z Z\end{array}$ & $\mathrm{H}$ & $\mathrm{D}$ & G & $\mathrm{U}$ & $\mathrm{D} \%$ & $\mathrm{H}$ & D & G & $\mathrm{U}$ & $\mathrm{D} \%$ & $\mathrm{H}$ & D & G & $\mathrm{U}$ & $\mathrm{D} \%$ & $\mathrm{H}$ & D & G & $\mathrm{U}$ & $\mathrm{D} \%$ \\
\hline 1 & 6 & 17 & 7 & 0 & +37 & 8 & 19 & 3 & 0 & 37 & 4 & 23 & 3 & 0 & +63 & 18 & 59 & 13 & 0 & +46 \\
\hline 3 & 8 & 11 & 11 & 0 & +10 & 5 & 15 & 10 & 0 & +3 & 8 & 16 & 6 & 0 & +27 & 21 & 42 & 27 & 0 & + \\
\hline 6 & 16 & 7 & 7 & 0 & -30 & 7 & 12 & 10 & 1 & +17 & 11 & 11 & 8 & 0 & 0 & 34. & 30 & 25 & 1 & -5 \\
\hline$a$ & 14 & 8 & 8 & 0 & -20 & 18 & 9 & 2 & 1 & -30 & 16 & 7 & 7 & 0 & -30 & 48 & 24 & 17 & 1 & -27 \\
\hline
\end{tabular}


我々は制止効果を時間錯誤の要因の1つをして新らた に提出したのであるが，もとより時留錯誤が制止効果と 同化のみによつて，さべての場合に完全に旡明されるも のとは思わない。Needham が指撂している樣に，時間 錯誤は多くの要因が複雜に重つて現象するものであろう から，その要因を1つづつ解きほぐしてゆくの力゙時間錯

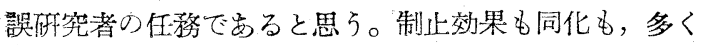
の要肉の中の1つとして考えられ䄈ばならない。しかし ながら，我ふの實驗の範圍內では，陽性時間錯誤は同化 及び制止効果に依つて證明が可能であり，本論文の害驗 が我々の目的とする陽性時間錯誤の解明に寄與する所が あれば幸いである。

\section{Abstract}

In the successive comparison of brightness, when the time interval between two stimuli is short, or when the ground is lighter than the istimuli, the positive time-error arises. In these two cases in wnich the positive time-error arises, a common factor seems to be operating. The results of our experiments suggest that the inhibitory effect exists in both cases as a common factor. When two stimuli are presented successively, the after-effect of the first excitation will remain in the nervous system. This after-effect will weaken the excitation of the second. Consequently the seocnd stimulus appears darker phenomenally. We name such an after-effect the inhibitory effect. We posit this effert as a physiological hypothesis. In the former theory of the time-error, arter-effect of the first excitation upon the next excitation has been neglected and the timeerror has been explained only by the change in the trace of the first excitation. The results of our experiments have proved that the former theory is deficie.t.

Our experiments of the successivc comparison of brightness gave us the following results.

1. When the time interval between two stimuli is short, the after.effect of the first excitation inhibits the second one and pnenomenally the second stimulus apfears darker. In such a way the postive timeerror arises.

2. When the ground is lighter than the stimuli, the after-effect of the excitation by the ground preceding the stimuli inhibits the next excitation by the first stimulus, the trace of the first stimulus assimilates the trace of the ground between the stimuli, and tne after-effect of the excitation by the ground nhibits the next excitation by the second stimulus.
The ground following the second stimulus does not essentially influence the judgment of comparison i. e.

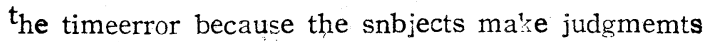
as soon as the second stimulus is presented. In such a way the positive time-error arises.

3. The inhibitory effect has the following characteristics.

a) The longer the duration of the first excitation is, the stronger and longer does the inhibitory effect of the first excitation act on the second one.

b) The longer the time interval between the two excitations is, the weaker is the inhibitory effect of the first excitation upon the second one.

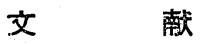

\section{（1）天野利武：比較過程の研究。1 1944}

(2) Gibson, J : Adaptation, after-effect and contrast in the perception of curved lines. J. Exp. Psy., vol. 16, 1933.

(3) Gibson, J. \& Radner, M. : After-effect and contrast in the perception of tilted lines J. Exp. Psy., vol. $20,1937$.

(4) Köhler, W.: Dynamics in Psychology. 1939.

(5) Kreezer, G.: The neurological level of the factors underlying time-errors. Amer. J. Psy., vol. 51. 1938.

(6) Lauenstein, O: Ansatz zur einer physiologichen Theorie des Ve:gleich und der Zeitfehler. P.y. Forsch., Bd. 17. 1932

(7) Laueustein, O.: Sukzessivvergleich von gebogenen Linien Psy Forsch., Bd. 22, 1938.

（8）前田恒：音强度繼時比較に於ける副次音の影響。 心研 XVI-XVII, 1941--1942.

(9) Neetham. J.: The time-error as a function of repeated experiments. Amer. J. Hsy., vol. 461934.

(10) Needham, J.: Interpolation effects with different intervals. J. Exp. Psy., vol. 18, 1935.

(11) Pratt, c.: The ti me-error in psychological judgments. Aner. J. Psy., vol 45, 1933.

（12）佐藤幸治：時間錯誤に於ける同化對比の因子に就 いて。䨘驗心理學研究, vol. 1, 1934

（13）和田陽平：音强度繼時比較に於ける時間錯誤に及 ぼす地音の影䅧。心砛 X, 1935

（14）和田陽年：音强度辯別に於ける時間:錯誤に對士る 刺㦸時間の影響。心研 XII，1937

(1949年8月20日受稿) 